\title{
TIBF CREDIT RISK OF ISLAMIC BANKS IN GCC COUNTRIES
}

\author{
Hamid A. H. Al-Wesabi and Nor Hayati Ahmad \\ University Utara Malaysia
}

\begin{abstract}
This paper is about factors affecting credit risk of Islamic banks in the Gulf Cooperation Council countries using website data covering 25 Islamic banks over 2006 to 2010. This study uses non-performing loans as a proxy for credit risk, which is the dependent variable with three macro-economic, and six firmspecific independent variables. We find income is significantly negatively related to credit risk, which is consistent with findings in other countries about credit risk. Some firm-specific variables such as leverage, liquidity are also relevant variables for credit risk, which results are also consistent with bank behavior reported in other studies. Credit risk is also broadly affected by both macro and firm-specific factors as found in other regions. Inflation and interest rates do not appear to be relevant. These results would suggest non-performing loan is broadly correlated with factors identified in other studies of banks.
\end{abstract}

Keywords: Credit risk; risk management; Islamic banks; gulf countries; nonperforming loans

JEL Classification: G32

\section{Introduction}

Islamic banking has developed as a niche banking serving customers with special financial needs, and Islamic banking products are compliant with a number of binding restrictions in the pricing, contracting, investments, and return characteristics compared with the mainstream banks, which dominate banking transactions. Over some 50 years, these Islamic niche banks in 76 countries have developed systems of operations that rely on the principles of Islamic Sharīah (legal system) pertaining to financial transactions. In those banks, Sharīahcompliant banking products are securitized, offered to meet the special needs of customers. Predominantly, these products are offered by the same banks that also sell products without the need for such compliance.

In order to achieve the perceived benefits to society as per the compliance with the broader social needs of the community, Islamic banks have spread around the world during the past five decades. It has a significant presence in the Middle Eastern countries, with Saudi Arabia, Dubai and Bahrain having 
the biggest Islamic banking assets compared with the other slightly smaller centers in Kuwait, Malaysia, Indonesia, Sudan, and Pakistan, etc. Bahrain with 27 banks has about half the number of Islamic banks in the Gulf Cooperation Council or GCC countries. Though it has the largest number of Islamic banks in GCC, in terms of assets, it is not the biggest center.

This paper is about finding the factors associated with credit risk of Islamic banks in the GCC countries. The paper is divided into five sections. In the next section, we describe the banks in the GCC countries and identify the research problem in the Islamic banking. The concept development and empirical results are found in section 3 . The findings are reported in section 4 and conclusions are presented in section 5 .

\section{Islamic Banks in the GCC Countries}

Islamic banks have been welcomed in many legal jurisdictions especially after the Bank of England decided about 12 years ago to license such banks as providing a niche banking services to special needs of customers. Prior to that acceptance of this niche banking, Islamic banks had slowly established in the Persian Gulf region, Southeast Asia, and few other places. The GCC countries as the recipient of oil-and-gas money found outlet as growth of the conventional and this niche banking. For example, Dubai Bank and the National Bank of Sharjah have become Islamic banks in the UAE. National Bank of Saudi Arabia, and Kuwait Real Estate Bank (Kuwait International Bank) recently converted their entire operations to be Islamic. ${ }^{1}$

In the light of competition in conventional banking and the increasing customer demand for Islamic banking services, banks such as Dubai Islamic Bank, Qatar Islamic Bank, and Al- Rajhi Bank ${ }^{2}$ in the GCC region expanded globally. At the end of $2009,{ }^{3}$ the Islamic banks' total assets were estimated to be over US $\$ 350$ billion, which by estimate is 43 per cent of total Islamic banking assets in the world compared with less than 10 per cent in 2003. That indicates a very high growth rate, and is expected to trend even higher on the back of the wider acceptance and increasing demand for banking products and services. The most important factors explaining the fast growth of Islamic banking assets in the GCC region are strong government involvement ${ }^{4}$ supporting their economies with ever increasing oil-and-gas wealth.

Economists classify GCC countries as developing countries. Oil and gas are the most important sources of income which contributing to upwards of 60 per cent of the economic activities. Furthermore, the energy sector is characterized by a high degree of energy-financing and higher average per capita income. The richest Muslim majority countries are located in this region: the average population of these countries is about 8 million per country, and

Booz \& Company www.booz.com and www.booz.com $/ \mathrm{me}$.

2 Previously known as Al-Rajhi Banking and Investment Corporation.

A report released by Kuwait Finance House (2010).

4 Standard \& Poor's Ratings Services. 
the GDP per capita is upwards of US\$ 24,000 (Laabas \& Limam, 2002). As a result, GCC countries face many urgent challenges to decrease their energysector dependency and develop non-energy sectors (Saif, 2009). It is obvious that macroeconomic performance would be affected by the changes in the oil/ gas prices or the fast developing alternatives to oil and gas. Instability in oil revenues would have an impact on the rates of growth in the economy through the effect on government expenditures. These countries are diversifying their exports in order to decrease the dependency on oil, while they are also trying to decrease their imports by growing basic manufacturing capacities (despite the influence of cheaper products from China that works against this effort). Economic diversification is also important for these countries to reduce risk or at least spread it, to limit the effect of a wide volatility in oil-and-gas prices, to create job opportunities and to promote economic development (Fasano \& Iqbal, 2003).

\subsection{Credit Risk in Islamic Banks}

Islamic banks in these countries still face several challenges in introducing workable reforms and processes to improve the development of the Islamic finance on a larger scale. One obstacle to improving performance of these banks is the lack of knowledge about the dynamics of their credit risk. Hence, a study of their credit risk may provide policy-relevant findings for their intended reforms to be considered. Credit risk especially in mushārakah, murārabah, salam and istisnāh contracts is studied. The expected risk in these contracts arises as a result of inability of debtors to meet their financial commitments on the dates of maturity. Consequently losses are incurred by Islamic banks. To minimize risk, Islamic Sharī' ah allows collateral which is considered as secured against the debt risk while third-party guarantees have also been introduced in addition to the loan loss reserve (LLR) to forestall credit risk. Islamic banks are still no exception to the four main types of risks that lead to systemic failure. Of the four, the most critical one is the credit risk (Fleifel, 2009).

According to Chapra and Khan (2000) and Khan and Ahmed (2001), credit risk is an important financial risk that is included within default risk, which covers more than three-quarters of the risks in an average Islamic bank's asset portfolios in the banking book. Credit risk causes more than three-quarters of Islamic bank failures. Credit risk appears greater than other risks, especially with PLS (profit-and-loss-sharing) modes of financing. Furthermore, default risk also introduces market risk and liquidity risk. On the other hand, in the modes of Non-PLS contracts such as muräbahah and ijärah, market risk is higher than the credit risk. This is, given the fixed income mode adopted in these contracts, the rate of bank profit is affected by the market's volatility (Khan \& Ahmed, 2001).

According to Al-Jarhi and Iqbal (2001), most GCC Islamic banks prefer fixed return modes, especially muräbahah modes, which represent the dominant form of financing. They found that the share of mushärakah-mudārabah in the total financing is smaller than the share of murābahah (that is to say, murābahah 
and ijärah form 75 per cent of the total of financing with only 25 per cent mushärakah-mudārabah, istisnāh and salam). ${ }^{5}$ The dominant contracts are not based on PLS principle. These are akin to purchasing good/services or leasing of capital goods/consumer durables. The returns to investors are fixed, while the PLS-based instruments are less dominant. Therefore, returns to investors would depend on the volatility in the market. Hence, Islamic banks try to aim for a balance between the two modes of non-PLS and PLS financing modes. There is expectation that the two modes have significantly different impacts on banking credit risk formation (Al-Jarhi \& Iqbal, 2001). Therefore, Islamic banks should be operationally well-prepared to manage credit risks to ensure the maintenance of their performance as well as gain growth.

There are many factors affecting credit risks. This topic has been studied widely in the case of conventional banking (Ahmed \& Nizam, 2004). This study examines the factors affecting credit risk of banks in the GCC countries. Another major significant and unique risk that Islamic banks face is the Sharī' ahcompliance risk. However, that is not included in the present study.

The research questions that guide the research are about what factors affect credit risk of the sample of Islamic banks in the GCC countries. The secondary question is to examine how the credit risk has been affected by the 2008-9 Global Financial Crisis.

\section{Literature Review}

\subsection{Delegated Monitoring Theory}

Delegated Monitoring Theory explains the process by which banks are justified as providing financial intermediation services to transfer deposit funds of surplus units (mainly households) making deposits enabling banks to act as their delegated monitors by making loans to deficit units (producers): Diamond (1984; 1996). Monitoring is possible through the collection of required information about the firm (the investor) on the grounds of safeguarding the loans from defaulting. Further, the banks impose restrictive conditions on the borrower to forestall firms from putting other parties ahead of paying the debt and the returns to the banks. That process incurs costs of monitoring on banks as a result of monitoring and executing the debt contracts. Therefore, delegated monitoring theory is one of the most significant theories to explain why banks have to rely more on capital and less on labor (Matthews \& Thompson, 2005; 2008).

Delegated Monitoring Theory as applied to Islamic banking has to be reinterpreted using the profit-and-loss-sharing mode to take into consideration the asymmetric information problem that would occur between Islamic bank (the agent) and the counterparty (firm) when the bank has insufficient information about the actual profits of the counterparty. Also the asymmetric information

Statistics of the General Council for Islamic banks, Bahrain, (2001). 
problem could also occur in the non-PLS mode such as in murābahah, in the event of external events such as systemic risk from other banks that may cause non-performance of the contracts of a borrower (Khan \& Ahmed, 2001).

\subsection{Review of Findings}

Many studies identify financial risk as one of the most important challenges for Islamic banking. Islamic banks are affected by many issues related to this risk. According to Makiyan (2008), risk management in Islamic banking is still not effective enough to face the major challenges of financial risk. One needs to understand many issues better to be able to apply innovative and appropriate solutions to prevent financial risk attributes of financial products. Islamic permissible modes of financing (PLS such as murārabah or non-PLS such as murābahah) need many measurements of risk such as income recognition, adequacy of collateral to be available, etc. (Makiyan, 2008).

According to Hasan and Dridi (2010) whose research is covering both types of banks in many countries, Islamic banks were affected by the crisis quite differently than conventional banks. The decline in profitability of some Islamic banks in 2008 was actually a result of weakness in the practices of risk management. But generally, credit and asset growth in Islamic banks were better than in conventional banks in 2008-9.

Iqbal, Ahmad and Khan (1998) present evidence in their study to the effect that most of the Islamic banks in GCC countries use both fixed return modes and variable return modes. Even though PLS modes are preferable but the share of these funding modes in the total financing is very small, about a quarter or less than the share of non-PLS modes. Murābahah mode dominates all other modes. This occurs perhaps due to bankers wanting to avoid the greater credit risk in the PLS modes, apart from the acute asymmetric information problem in such contracts.

Khan and Ahmed (2001) define credit risk as a failure of the counterparty to meet bank obligations according to the agreed terms. This risk would arise in Islamic banks as a form of settlement/payment risk when the banks pay money before they receive the assets (e.g., salam or istisnāh) or deliver assets before receiving cash (as in muräbahah contract). Khan and Ahmed (2001) also show the diversification effect of granting loans on the portfolio. They mention that the effective means of reducing credit risk is to actually reduce the risk by forming a minimum risk portfolio in the loan book. In this manner, risk management can be minimized to handling the systematic risk and avoid (better still lessen) the need for managing non-systematic risk in the bank's portfolios. In this sense, the conventional wisdom of portfolio risk minimization works in all banks.

Thiagarajan, Ayyappan and Ramachandran (2011), who studied Indian economy, find that the lagged non-performing asset (NPA) has a positive influence on the current NPA and that there is a significant inverse relationship between credit risk and GDP. Thus, the GDP growth helps the banking system while having non-performing loans at an acceptable level. In fact, 
both macroeconomic factors and bank-specific factors play important roles in determining the credit risk of the banking system.

Ahmed, Akhtar and Usman (2011) state that the credit risk is highly affected by size of the bank, capital adequacy and debt equity ratios. They also find a positive and statistically significant relationship with credit risk at 0.05 per cent and 0.01 per cent levels respectively. The asset management quality has a significant negatively relationship on credit risk. Therefore all explanatory variables appear to affect credit risk. They find a statistically insignificant relationship between NPL and credit risk in the Indian banks.

Ahmad and Ariff (2007) search across two types of conventional banking systems, banks in emerging economies and their counterparts in several developed countries by comparing them. They find that several factors are significant and relevant to credit risk, whether the banks are from emerging economies or developed economies. Regulatory capital would be increased to adequately absorb any losses so the capital is significantly positively relevant to credit risk. However, their results suggest that some countries with undercapitalized banks still face more risks, meaning that the credit risk is affected significantly negatively. Management quality, which is a ratio of earning assets to total assets affect credit risk significantly positively. Loan loss provision as a ratio of total loans affects credit risk significantly positively. These researchers use NPL, which is bad loans, as a measure for credit risk, as in this paper. They highlighted that emerging economy banks have a higher credit risk than their counterparts in developed economies. Since, GCC countries are classified as emerging economies so the banking system is likely to be facing higher credit risk as well.

Das and Ghosh (2007) examine both macroeconomic and microeconomic factors that affect credit risk of Indian banks, a case of banks from emerging economy. Generally, the results show that real loan growth, GDP growth and (at the bank level) bank size, real interest rate and operating expenses have significant influences on credit risk. The effects of these factors are respectively mixed. They employ NPL instead of credit risk as a proxy for dependent variable.

Khemraj and Pasha's (2010) study ascertains what determines the NPL in the Guyanese banking system. They find GDP growth is significantly related inversely to NPL and the effective exchange rate has a positive impact on NPL, given currency depreciation. They also find that real interest rate has a significantly positive effect on NPL, as also is the case for inflation and loan growth. However, the size of bank has mixed positive and negative relationship. The ratio of loans to total asset was negatively related to NPL.

Al-Smadi (2010) applies risk index to measure exposure to risk of several Jordanian banks, using data over 1995 to 2008. His findings indicate that three major macroeconomic variables are statistically significant. They are GDP, inflation rate and market interest rate. He provides evidence that internal variables have effects on credit risk more than external variables. He finds that the relationship between GDP and credit risk is significantly negative, while it is positive on inflation and also positive on interest rate. There are five bank- 
specific variables: NPL, loan concentration in risky sectors, loan growth, bank size and net interest margin in their study. These five variables have significant relationship with credit risk. Loan growth and loan concentration in risky sectors have positive effects as well. Bank size has a negative effect on credit risk.

A study on the determinants of credit risk (Ahmad \& Nizam, 2004) in Malaysia for the period 1996 to 2002 compares Islamic banks and conventional banks. They use non-performing loans for credit risk exposure. Their results show that three variables are significantly related to credit risk of Islamic banking: management efficiency, risk weighted asset, and natural logarithm of total assets. All these have positive relationships with credit risk. Additionally, four variables significantly affect credit risk in the cases of conventional banking: these are risky sector loan exposure, regulatory capital, loan loss provision, and risk-weighted assets. They find positive relationship with credit risk except in the case of regulatory factor. In addition, the authors find a higher R-square value in conventional banking compared to Islamic banking: 75.6 per cent and 34 per cent respectively. This denotes that the combined impact of these variables is stronger on conventional bank credit risk than Islamic bank credit risk.

\section{Data and Methodology}

This section explains how this study is conducted in terms of research design, sample, data collection, and analysis. The main questions that guide the study are restated as follows: What are the variables which influence credit risk? What is the impact of Global Financial Crisis on the credit risk? All questions apply to Islamic banks in the GCC countries. Once these variables are identified, the management of credit risk will be manageable using the variables to mitigate risk and improve credit risk management. These variables are selected as suggested in several studies as being important. These are explained in this section, together with all the measurements of variables, the model, framework and the hypotheses development.

\subsection{Theoretical Framework and Model}

This section explains the modeling of the variables that relates NPL as credit risk to a number of assumed independent variables widely used in such studies: LNTA (natural log of total assets), MGTEFF (management efficiency), REGCAP (regulatory capital), L/D (proportion of loan to deposit), RSKAST (risky asset which is real estate asset in GCC countries according to the published reports) and LLP (loan loss provision). These variables represent internal independent variables (Ahmad and Nizam, 2004). GDP (gross domestic product), INF (inflation rate) and LIBOR (London inter-banks offered rate) because Islamic banks in GCC countries usually link profit margin with that ratio) are external independent variables.

Regression model is used to test the variables affecting credit risk. According to past studies of Das and Ghosh, (2007); Ahmed and Ariff, (2007), 
there are nine variables in studies on credit risk. Some descriptive statistics are given in Appendix A. The test model is in Equation (1):

$$
\begin{aligned}
\text { CRit }= & \beta_{0+} \beta_{1} G D P_{\mathrm{it}+} \beta_{2} I N F_{\mathrm{it}+} \beta_{3} L I B O R_{\mathrm{t}}+\beta_{4} L N T A_{\mathrm{it}+} \beta_{5} M G T E F F_{\mathrm{it}} \\
& { }_{+} \beta_{6} R E G C A P_{\mathrm{it}+} \beta_{7}, \mathrm{~L} / \mathrm{D}_{\mathrm{it}+} \beta_{8} R S K A S T_{\mathrm{it}+} \beta_{9} \mathrm{LLP}_{\mathrm{it}+} \varepsilon_{\mathrm{it}}
\end{aligned}
$$

Where:

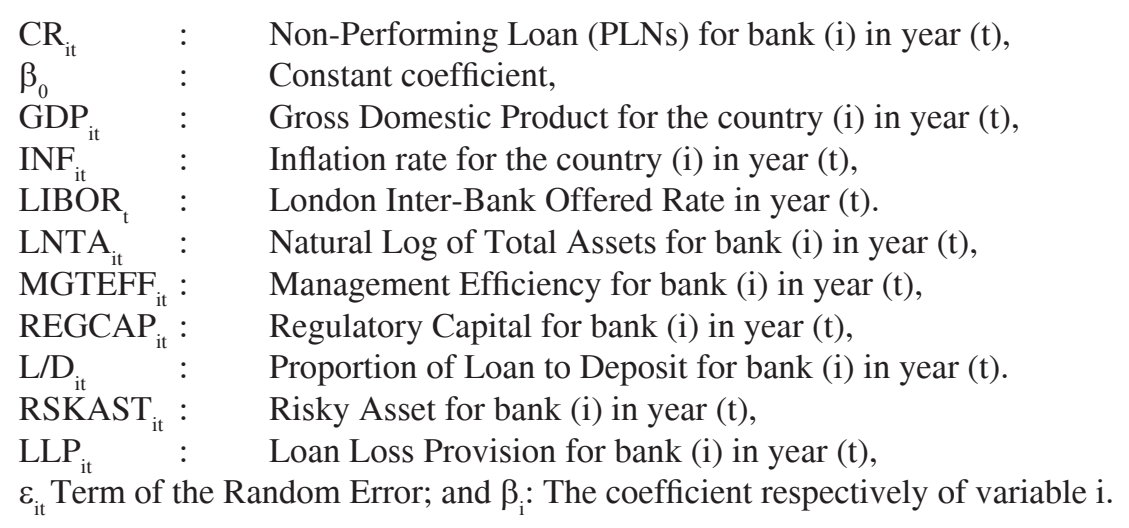

\subsection{Hypotheses Development}

The main aim of this investigation is to identify selected variables that affect credit risk. These variables are divided into two categories with one representing specific variables of banking and the other representing macroeconomic factors. Both have significant impact on credit risk according to literature.

$\mathrm{H}_{1} \quad$ : There is a negative relationship between GDP and credit risk in Islamic banks of GCC countries.

$\mathrm{H}_{2}$ : There is a positive relationship between inflation rate and credit risk in Islamic banks of GCC countries.

$\mathrm{H}_{3} \quad$ : There is a positive relationship between LIBOR and credit risk in Islamic banks of GCC countries.

$\mathrm{H}_{4} \quad$ : There is a negative relationship between size and credit risk in Islamic banks of GCC countries.

$\mathrm{H}_{5} \quad$ : There is a negative relationship between management efficiency and credit risk in Islamic banks of GCC countries.

$\mathrm{H}_{6} \quad$ : There is a positive relationship between regulatory capital and credit risk in Islamic banks of GCC countries.

$\mathrm{H}_{7} \quad$ : There is a positive relationship between proportion of loan to deposit and credit risk in Islamic banks of GCC countries.

$\mathrm{H}_{8} \quad$ : There is a positive relationship between a risky asset and credit risk in Islamic banks of GCC countries. 
Al-Wesabi and Ahmad: Credit risk of Islamic banks in GCC countries

$\mathrm{H}_{9} \quad$ : There is a negative relationship between the loan loss provision and credit risk in Islamic banks of GCC countries.

\subsection{Measurement of Variables}

According to Ahmed and Nizam (2004), Das and Ghosh (2007), and Al-Smadi (2010), credit risk is a dependent variable and is measured by NPL as a proxy. Definition of NPL in this study follows assumption in the form sent to previous studies and is measured as in the definitions that follow.

This study has two types of independent variables (external and bankspecific variables) the external variables are the macroeconomic factors and they are found as a figure or ratio form in the macroeconomic annual reports, thus easing the burden of measuring these variables by researchers. However, sometimes researcher can measure some variables in few cases. For example for the GDP, they use this equation: GDP $=\mathrm{C}+\mathrm{I}+(\mathrm{X}-\mathrm{M})+\mathrm{G}$. where $\mathrm{C}$ : Consumption, I: Investments, X: Exports, M: Imports and G: Government's expenditure. Regarding inflation rate, they use Consumer Price Index (CPI) and INF rate equal the rate of change of CPI and taken as the annual basis. As for the specific banking independent variables, they are measured in this study following measurements as in past studies. Size of bank (LNTA) is measured as follows:

NPLs $=\frac{\text { Impairment Loans }(\text { Financing })}{\text { Total Loans }(\text { Financing })}$

$L N T A=\log ($ Total Assets)

Management efficiency (MGTEFF) variable: MGTEFF $=\frac{\text { Earning Assets }}{\text { Total Assets }}$

Regulatory capital (REGCAP) variable: $\mathbf{R E G C A P}=\frac{\text { Tier } 1}{\text { Total } \text { Assets }}$

The proportion of loan to deposit (L/D) variable: $\mathbf{L} / \mathbf{D}=\frac{\text { Total Loans } \text { (Financing) }}{\text { Total Deposits }}$

Risky asset (RSKAST) variable: RSKAST $=\frac{\text { Investment in real estate asset }}{\text { Total Investment }}$

Loan loss provision $\left(\right.$ LLP) variable: $\mathbf{L L P}=\frac{\text { Total Provision or Allowance }}{\text { Total Loans } \text { (Financing })}$

Financing, besides loan, means it is based on PLS modes, which is different from the loan based on interest rate in conventional banking. Figure 4.1 shows the extent of the rise of credit risk especially in Kuwait in 2009. It is 
International Journal of Banking and Finance, Vol. 10, Iss. 2 [2013], Art. 8 104

noticed that credit risk generally increases over the period from 2006 to 2010, meaning that there is an imperfection in the credit risk management which is required to be examined and identified.

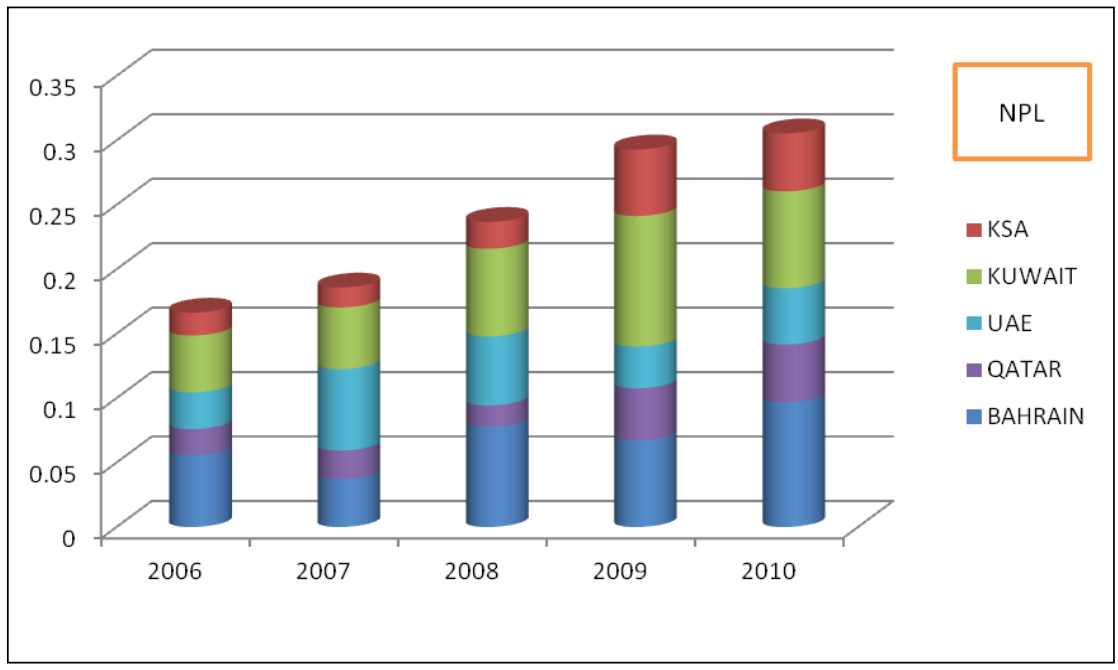

Figure 1: NPL in the Islamic banks in GCC countries

From Table 1, it is clear that the mean credit risk estimated is 0.043 for all of the banks in the test period, 2006-10. This is also shown in Figure 4.5 where the NPL increases from 3 percent in 2006 to 6 percent in 2010. This increase in the NPL is because of the rising in the impaired loans (financing in Islamic banks) compared to the total loans. The variance between banks in term to its credit risk exposure (standard deviation) estimated is 0.040 as shown in Table 1. Also the means of GDP, INF and LIBOR are 6.46, 4.94, and 0.029 respectively. The standard deviations are 5.53, 3.34 and 0.018 respectively.

Table 2 provides a summary of the regression results obtained from running a regression using NPL as dependent variable on the 9 independent variables as in the model developed in this paper. As can be observed, four factors are statistically significant: Management quality; L/D; Risk assets; GDP. The other factors are not significantly correlated with the credit risk. Overall, the regression provided significant model fit as judged by the F-ratio of 4.31 (not shown in the table). The coefficient of determination was 0.6578 meaning that the variables explained 65.78 per cent of the variation in the credit risk as measured by the NPL.

As is clear from the results, we have identified four factors out of the nine factors as being significantly correlated with the credit risk. These factors appear to make sense. Liquidity is of course a major issue in all banking systems, and this is of importance in managing credit risk. Management quality has consistently come up as a major factor in other studies. 
Al-Wesabi and Ahmad: Credit risk of Islamic banks in GCC countries

Table 1: Descriptive statistics of variables used in GCC countries

\begin{tabular}{lccc}
\hline Variables & Mean & Std. deviation & $\mathrm{N}$ \\
\hline NPLs & 0.0433 & 0.0402 & 125 \\
LNTA & 22.281 & 1.324 & 125 \\
MGTEFF & 0.771 & 0.1979 & 125 \\
REGCAP & 0.237 & 0.195 & 125 \\
L/D & 2.496 & 5.455 & 125 \\
RSKAST & 0.211 & 0.142 & 125 \\
LLP & 0.086 & 0.432 & 125 \\
GDP & 6.464 & 5.531 & 125 \\
INFL & 4.939 & 3.337 & 125 \\
LIBOR & 0.028 & 0.0181 & 125 \\
\hline
\end{tabular}

Table 2: Coefficients from regression analysis

\begin{tabular}{cccccc}
\hline \multicolumn{7}{c}{ Unstandardized } & Standardized & & \\
Coefficients & Coefficients & t-values & Significance \\
& B & $\begin{array}{c}\text { Std. } \\
\text { Error }\end{array}$ & Beta & & \\
\hline Constant & -0.018 & 0.097 & & -0.186 & .853 \\
LNTA & 0.005 & 0.004 & 0.157 & 1.114 & .268 \\
MANGEFF & -0.065 & 0.020 & -0.318 & $-3.189 * *$ & .002 \\
REGCAP & 0.010 & 0.031 & 0.049 & 0.326 & .745 \\
L/D & 0.002 & 0.001 & 0.300 & $2.852 * * *$ & .005 \\
RSKAST & 0.053 & 0.023 & 0.188 & $2.323 * *$ & .022 \\
LLP & -0.007 & 0.007 & -0.077 & -0.980 & .329 \\
GDP & -0.002 & 0.001 & -0.208 & $-2.179 * *$ & .031 \\
INF & 0.000 & 0.001 & -0.002 & -0.023 & .982 \\
LIBOR & -0.119 & 0.209 & -0.053 & -0.569 & .571 \\
\hline
\end{tabular}

This study confirms that for Islamic banks, the higher the risky assets in the total asset portfolio the higher is Islamic bank's credit risk. Finally, GDP or income is a significant factor. If GDP growth is declining, the chances are high that credit risk will go up. We did not find the other five factors to be 
significant, although the signs are sometimes revealing of the directions of the effect. Nevertheless, not finding some of the factors to be relevant is consistent with other studies such as Ahmad and Ariff op cit.

\section{Conclusion}

The aim of this paper is to make a preliminary study of how credit risk is associated with key macroeconomic and bank-specific factors in the fast-growing Islamic banking region, namely the Gulf region. Findings from this study are likely to be the first on this policy-relevant topic. Unlike in the conventional banking, no one knows how credit risk is driven by what factors in Islamic banks. We developed a simple cross-sectional model using annual data of 25 established commercial banks over a reasonable length of time to relate credit risk to the already verified and widely used nine potential factors used in studies of credit risk of conventional banks.

The results of this study reveal that the Islamic banks in the Gulf region have significant credit risk as measured by the size of the non-performing loans. Also, the credit risk is largely determined by such common factors (that is common with conventional banking) as liquidity, management quality, risky assets in portfolios and GDP. These results may be treated as preliminary from six countries in one region of this fast growing banking industry that has spread to 76 countries. More research of other banks in other regions may reveal how credit risk is formed in this new niche banking across the world. When such further studies are made, it would be possible to frame a strategy on how Islamic banks would manage credit risk.

Author Information: This paper is one of three papers that were selected as the best papers considered for award at the Fifth Foundation of Islamic Finance Conference at Langkawi, Malaysia in July, 2012. The authors wish to record their appreciation for this award and also thank the discussant and participants at the Conference for their generous comments. Nor Hayati Ahmad is a professor in UUM College of Business, and may be contacted at ayati@uum.edu.my. Hamid Abdulkhaleq Hasan Al-Wesabi may be contacted at hameedalwesabi@ yahoo.com.

\section{References}

Ahmad, N. H. \& Ariff, M. (2007). Multi-country study of bank credit risk determinants. The International Journal of Banking and Finance, 5, 135152.

Ahmad, N. H. \& Nizam. A, S. (2004). Key factors influencing credit risk of Islamic bank: A Malaysian case. Review of Financial Economic 2. 
Al-Wesabi and Ahmad: Credit risk of Islamic banks in GCC countries

Jeddah: Islamic Development Bank-Islamic Research and Training Institute.

Ahmed, N., Akhtar, M. F., \& Usman, M. (2011). Risk management practices and Islamic banks: An empirical investigation from Pakistan. Interdisciplinary Journal of Research in Business, 1(6), 50-57.

Al-Jarhi, M. \& Iqbal M. (2001). Islamic Banking: Answers to some frequently asked questions. Jeddah: Islamic Development Bank-Islamic Research and Training Institute.

Al-Smadi, M. O. M. (2010). Credit risk, macroeconomic and bank specific factors in Jordanian banks. PhD Thesis, Universiti Utara Malaysia.

Chapra, M. U. \& Khan, T. (2000). Regulation and supervision of Islamic banks. Jeddah: Islamic Development Bank-Islamic Research and Training Institute.

Das, A. \& Ghosh S. (2007). Determinants of credit risk in Indian state-owned banks: An empirical investigation. Economic Issues, 12(2), pp 48-66.

Diamond, D. W. (1984). Financial intermediation and delegated monitoring. The Review of Economic Studies, 51(3), 393-414.

Diamond, D. W. (1996). Financial intermediation as delegated monitoring: A simple example. Federal Reserve Bank of Richmond Economic Quarterly, 82(3), pp 51-66.

Fasano, U. \& Iqbal, Z. (2003). GCC countries: From oil dependence to diversification. Washington: International Monetary Fund.

Fleifel, B. A. (2009). Risk management in Islamic banking and finance: The Arab finance house example. An unpublished thesis submitted to the University of North Carolina Wilmington, USA.

Greuning, H.V., \& Z. Iqbal. (2008). Risk analysis for Islamic banks. Washington: World Bank.

Hasan, M. \& Dridi, J. (2010). The effects of the global crisis on Islamic and conventional banks: A comparative study. IMF Working Paper, WP 10/201.

Iqbal, M., Ahmad, A. \& Khan, T. (1998). Challenges facing Islamic banks. Jeddah: Islamic Development Bank-Islamic Research and Training Institute.

Iqbal, Z. (2009). Impact of global financial crisis on IDB member countries: The case of Gulf Cooperation Council and sub-Saharan Africa. The Pakistan Development Review, 47(4), pp. 583-601.

Khan, T. \& Ahmed, H. (2001). Risk management: An analysis of issues in Islamic financial industry. Jeddah: Islamic Development Bank-Islamic Research and Training Institute.

Khemraj, T. \& Pasha, S. (2009). The determinants of non-performing loans: An econometric case study of Guyana. Paper presented at The Caribbean Centre for Banking and Finance Bi-Annual Conference on Banking and Finance, St. Augustine, Trinidad.

Laabas, B. \& Limam I. (2002). Are GCC countries ready for currency union? Kuwait: Arab Planning Institute. 
International Journal of Banking and Finance, Vol. 10, Iss. 2 [2013], Art. 8 108

Makiyan, S. N. (2008). Risk management and challenges in Islamic banks. Journal of Islamic Economics, Banking and Finance, 4(3), 45-54.

Matthews, K. \& Thompson, J. (2008). The economics of banking. Chichester: John Wiley and Sons.

Saif, I. (2009). The oil boom in the GCC countries, 2002-2008: Old challenges, changing dynamics. Washington: Carnegie Endowment for International Peace.

Thiagarajan, S., Ayyappan, S., \& Ramachandran, A. (2011). Credit risk determinants of public and private sector banks in India. European Journal of Economics, Finance and Administrative Sciences, 34, 147154. 
Al-Wesabi and Ahmad: Credit risk of Islamic banks in GCC countries

APPENDIX A

Table A1: Anova

\begin{tabular}{llccccc}
\hline \multicolumn{1}{l}{ Model } & $\begin{array}{c}\text { Sum of } \\
\text { Squares }\end{array}$ & df & Mean Square & F & Sig. \\
\hline \multirow{2}{*}{1} & Regression & .064 & 9 & .007 & 6.035 & .000 \\
& Residual & .136 & 115 & .001 & & \\
& Total & .201 & 124 & & & \\
\hline
\end{tabular}


International Journal of Banking and Finance, Vol. 10, Iss. 2 [2013], Art. 8 
Al-Wesabi and Ahmad: Credit risk of Islamic banks in GCC countries

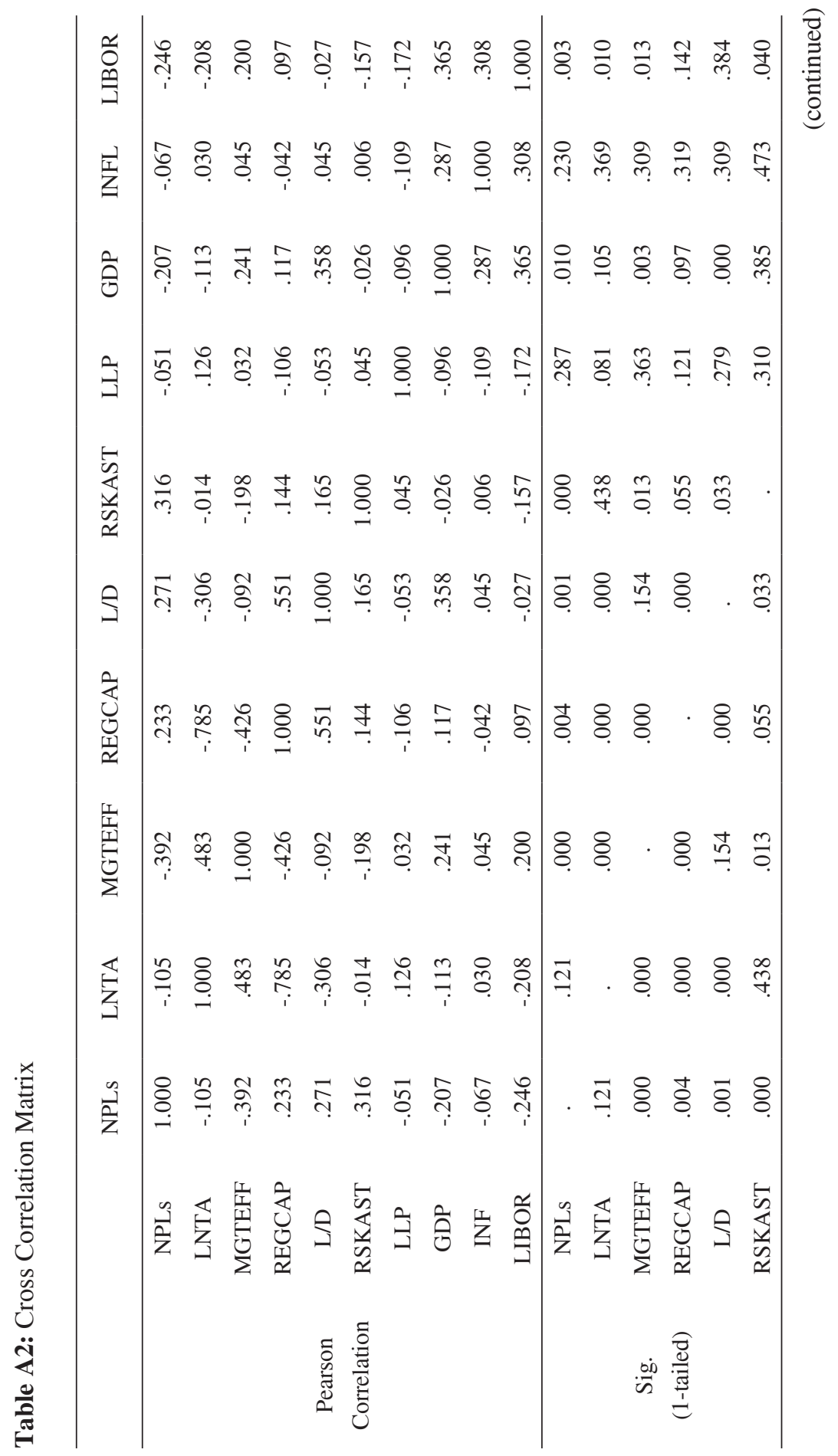


International Journal of Banking and Finance, Vol. 10, Iss. 2 [2013], Art. 8 112 The International Journal of Banking and Finance, Vol. 10. Number 2, August 2013: 1-24

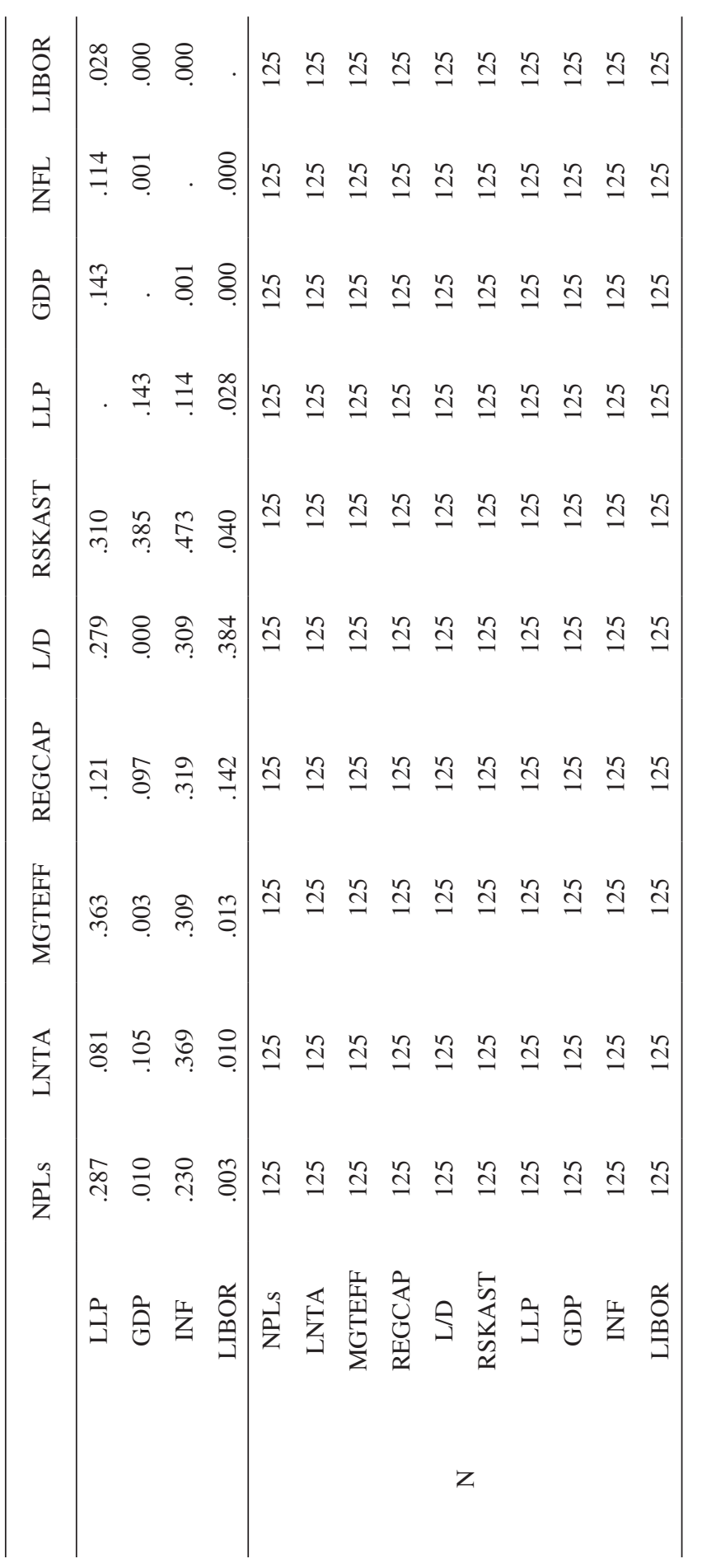

